\title{
Fordítástudomány tegnap és ma A XXI. TransELTE konferencia krónikája
}

\section{(ELTE BTK Fordító- és Tolmácsképző Tanszék, Gólyavár, 2019. március 21-22.)}

\author{
Eszenyi Réka \\ E-mail:reszenyi@caesar.elte.hu \\ Fuhász-Koch Márta \\ E-mail:juhaszkochmarta@gmail.com
}

\begin{abstract}
2019 tavaszán huszonegyedik alkalommal került megrendezésre az ELTE Fordító- és Tolmácsképző Tanszékének tavaszi konferenciája, melynek témája a fordítástudomány, a fordítás és tolmácsolás elmélete és gyakorlata. Az idén is több száz fordító és tolmács, kolléga és volt hallgató regisztrált az eseményre, melyet Prof. Dr. Károly Krisztina, az ELTE BTK dékánhelyettese nyitott meg. Beszédében kitért a tanszék képzéseinek sokszínüségére és népszerüségére: két mesterképzésünk és négy szakirányú továbbképzésünk keretében évente több mint száz szakember, fordító, tolmács, lektor, terminológus és audiovizuális fordító szerez képesítést a tanszéken.
\end{abstract}

\section{1. nap: A nyelvszakos fordítótól a nyelvi mérnökig}

A délelőtt megnyitását a „Les voyages forment la jeunesse” francia nyelvű eszszéverseny díjátadója követte. A díjakat Boros István, a Francia Becsületrend és Nemzeti Érdemrend Magyar Tagjainak Szövetsége Egyesület elnöke adta át a tanszék két másodéves hallgatójának, Fehér Fruzsinának és Veszprémi Zsófiának, akik meg is osztották franciaországi utazásukról, kalandjaikról, és belső fejlődésükről szóló esszéjüket a közönséggel, francia nyelven.

A következő előadó, Filip Majcen munkahelye a Tolmácsolási Szolgáltatásmenedzsment és Szakmai Támogatás Igazgatósága, Tolmácsolási Főigazgatóság, Európai Bizottság. Majcen úr az intézmény igazgatójaként hangsúlyozta a tudás megosztásának fontosságát, az intézmény partneri kapcsolatát az EU egyéb, nyelvi szolgáltatást nyújtó intézményeivel, a tolmácsképzést folytató fel-

Hivatkozás: Eszenyi R., Juhász-Koch M. 2019. Fordítástudomány tegnap és ma: A XXI. TransELTE konferencia krónikája. (ELTE BTK, Fordító- és Tolmácsképző Tanszék, Gólyavár, 2019. március 21-22.) Forditástudomány 21. évf. 2. szám. 106110. DOI: https://doi.org/10.35924/fordtud.21.2.8 
sőoktatási intézményekkel, más nemzetközi szervezetekkel és szakmai társulásokkal. A tolmácsolás jelenéről és jövőjéről beszélve kihagyhatatlan témaként merültek fel a tolmácsolást támogató nyelvtechnológia újdonságai, és a digitális kabin fogalma, amely a konferenciatolmácsok munkáját segítő számtalan digitális eszköz tolmácsolás közbeni alkalmazását jelenti. Ezek az eszközök mobiltelefonon, notepaden vagy laptopon (esetleg pc-n) elérhető applikációk és weboldalak, amelyek a kabinban dolgozó konferenciatolmácsokat többek közt a szükséges szókincs, terminológia és háttérinformáció gyors keresésében segítik.

A délelőtt ezután következő részében eltávolodtunk a számunkra ismerős európai rendszerektől, és két kínai vendég, Wu Bo és Dou Weilin, a sanghaji East China Normal University oktatói tartottak előadást „Kínai perspektíva a fordítástudományban: tegnap és ma" címmel. Az előadók angol nyelven mutatták be Kína sok évszázadra visszanyúló, gazdag fordítási hagyományát, amely tanszékünk, mint a Magyarországon egyedüli kínai-magyar nyelvpárt is felkínáló program számára, különös jelentőségü.

$\mathrm{Az}$ EU-n kívül eső fordítástudományi kalandozások sora Grúziában folytatódott. Khatuna Beridze, a Batumi Shota Rustaveli State University oktatója „A fordítók és tolmácsok jogai Grúziában” címmel tartott előadást, amelyből kiderült, hogy Grúziában a tolmácsok munkájának szabályozásában és biztosításában nagy utat kell még bejárni. A szakma kereteinek kiépítésében nagy szerepet kaphat az egyetemi fordító- és tolmácsképzés beindítása Grúziában, amelynek előkészítéséhez grúz vendégünk európai tolmácsképző intézményekben, többek közt az ELTE FTT-n tett látogatást.

A konferencia ezután újra az unió keretei közé kalauzolta vissza a hallgatóságot: Belgiumban élő és kutató kolléganőnk, Balogh Katalin a Leuveni Katolikus Egyetemről a „Gyermekek meghallgatása jogi tolmács közvetítésével” címü előadásában a Co-Minor IN/QUEST-et, egy olyan európai projektet ismertetett, amelyet több európai (belga, holland, magyar, egyesült királyságbeli, olasz és francia) egyetem a tagországok hatóságaival karöltve folytatott le annak érdekében, hogy a bíróságokon és rendőrségeken folyó eljárásokban meghallgatott gyermekeknek tolmácsoló szakemberek munkájukat minél professzionálisabban, ugyanakkor kíméletesebben és gyermekbarátabb módon tudják végezni. Az előadáson betekintést nyerhettünk a kutatás műhelytitkaiba és hallhattunk annak eredményeiről, amelyek az interneten minden érdeklődő számára elérhetőek (Balogh és Salaets 2015).

A délelőtt egy újabb kutatási projekt ismertetésével folytatódott: tanszékünk oktatója, Felekné Csizmazia Erzsébet „Gyakorló tolmácsok blattolása, avagy miről árulkodik a szemmozgáskövetés" címmel doktori kutatásának legújabb eredményeit osztotta meg az egybegyưltekkel. A kutatás témája a blattoló, vagyis írott szöveget szóban a célnyelvre tolmácsoló tolmácsok és tolmácshallgatók szemmozgása közti különbség vizsgálata volt. A kutató a modern technika eszközeit hívta segítségül a szemmozgások követéséhez, és a tolmácsok fixációjának idejét, helyét és időtartamát vizsgálva mutatott ki különbségeket. Megtudhattuk, hogy a profi tolmácsok általában kevesebb fixációval, és gyorsabban haladtak kevesebb tapasztalattal rendelkező társaikhoz hasonlítva, és több stratégiát is bevetettek, melyek által tolmácsolásuk folyamatosabb lett. 
A délelőtti blokkot Marcin Feder, az Európai Parlament DG LINC osztályvezetője zárta, aki „A tolmácsok tudásprofilja” címmel a modern tolmácstól elvárt készségekről beszélt. Feder úr lengyel-angol-svéd nyelvkombinációjával, az EP lengyel kabinfönökeként hitelesen írta le a nyelvi felkészültség fontosságát a tolmácsok életében, és az innováció, a technikai eszközök megismerésének fontosságát. Hitelességéről tanúskodik, hogy a fordítástámogató eszközök használatáról szólt a 2000-es évek elején doktori disszertációja is, egy olyan időszakban, mikor a technikai eszközök napjainkra jellemző rohamos térfoglalása még nem volt ilyen egyértelmü.

A konferencia második, nyelvi mérnökség témájú blokkja két részből állt. A téma apropója, hogy a tanszék 2019-től elsőként az országban nyelvi mérnök képzést hirdet meg, melynek lényege a szakfordító technikai kompetenciájának bővítése. A technikai kompetencia körébe sorolható többek közt a fordítástámogató eszközök professzionális szintű használata, a szövegek előkészítése az eszközzel történő fordításhoz, majd a fordítás minőségének ellenőrzése. Emellett feladata egy nyelvi mérnöknek a terminológiai adatbázisok építése és a fordítómemória karbantartása. A szekció első előadója, Dirk Verbeke a belga Televic cég képviseletében „Technológiák oktatása, MI, rossz big data a fordítás és tolmácsolás területén - legjobb gyakorlatok" című előadásában egy oktatásban is felhasználható fordítástámogató eszközt mutatott be, amely lehetővé teszi fordítások automatikus lektorálását. A folyamathoz, a fordítómemóriák építésének analógiájára, fordítási hibákból építhetünk memóriát, és ennek segítségével a javítási vagy lektorálási idő akár harmadára is csökkenthető.

A technika új vívmányai valóban megkönnyíthetik, gyorsabbá és pontosabbá tehetik a fordítást, ám az igazsághoz az is hozzátartozik, hogy csak az eszközöket kellően ismerő felhasználó kezében valósul meg mindez. Az eszközök megismerése, a fordító technikai kompetenciájának fejlesztése pedig idő- és energiabefektetést kíván meg a felhasználótól, különösen míg eljut a professzionális eszközhasználat szintjéig. A délután következő része „Mérnök-e a nyelvi mérnök" címmel, egy panelbeszélgetés keretében ezt a témát boncolgatta. A beszélgetés résztvevői Hidy Mátyás, szabadúszó informatikai fordító, Lesznyák Ágnes, a DGT Magyar Nyelvi Osztály munkatársa, Nagy Levente, szabadúszó fordító, Jánosy Márton, az Edimart fordítóiroda junior nyelvi mérnöke, Varga Zsolt, a MemoQ Zrt Product Ownere, és Urbán Miklós, a RWS Moravia IT Senior Solutions Architectje voltak. A szakemberek mind végeznek nyelvi mérnöki tevékenységet (is) mindennapi munkájuk során, és a kérdésre, hogy érdemes-e időt és energiát fektetni a mérnöki teendők elsajátítására, egyértelmü igen volt a válasz. A bölcsész-nyelvszakos háttérrel rendelkező fordítók gyakran idegenkednek az ilyen jellegü informatikai ismeretektől, de mint a beszélgetésből kiderült, bár lehet fordítástámogató eszközök nélkül is fordítani, egyre kevésbé érdemes.

A csütörtöki nap utolsó, ám sokak érdeklődését felkelő témája az audiovizuális fordítás volt, amely szintén két féléves szakirányú továbbképzésként van jelen a tanszék kínálatában. A TransELTE konferencia audiovizuális fordítási blokkja idén különleges aspektusát mutatta be a szakterületnek. A szakma neves résztvevőinek segítségével végigkövethettük a szöveg útját a fordítótól 
a befogadóig. Technikai okok miatt Sereg Judit szinkrondramaturg, audiovizuális fordítás oktató és kutató előadása elmaradt, így a blokk rögtön egy panelbeszélgetéssel kezdődött, melynek keretében Sereg Judit kérdései alapján Majoros Eszter szinkronrendező, Pataricza Eszter szinkrondramaturg, Bogdányi Titanilla és Szatory Dávid szinkronszínészek valamint Jacsó Bence hangmérnök betekintést nyújtott a szinkronszakmába.

Megtudhattuk, hogy a filmszövegek egészével először az audiovizuális fordító majd a szinkronrendező találkozik, a színészek pedig általában csak a felvételen, és ott is a csak annak a karakternek a szövegével, akit szinkronizálnak. Létezik egy úgynevezett besoroló vetítés, amely a nagyobb filmek felvételét előzi meg. Ennek keretében a szinkrondramaturg ráolvassa a szövegkönyvet a filmre, és az esetlegesen felmerülő hibákat ekkor javítják ki. A felvétel folyamatáról megtudhattuk, hogy manapság ritka a páros felvétel, vagyis egy jelenetben résztvevő karakterek szövegét is külön veszik fel a stúdiók.

A rövid panelbeszélgetés után következett a szinkronfelvétel imitálása. A jelenlévő szakemberek az Escobar cimű 2017-es filmdráma egy jelenetének szinkronizálásával illusztrálták a szinkronfelvétel folyamatát. Majoros Eszter instrukciói alapján a két főszereplőt, Penélope Cruzt és Javier Bardemet Bodgányi Titanilla és Szatory Dávid szólaltatta meg mikrofonban magyarul a Pataricza Eszter által fordított szövegkönyv segítségével, Jacsó Bence hangmérnök pedig a szinkronfelvétel technikai megvalósításáért felelt. A felvétel közben is megtudhattunk számos szakmai érdekességet. Szatory Dávid például elárulta, hogy valószínűleg Javier Bardem szerepére őt élesben nem castingolták volna, mert más típusú a hangja, éppen ezért a felvétel alatt kissé elmélyítette a hangját. Bodgányi Titanilla szintén megemlítette, hogy neki is sokkal fiatalosabb a hangja, mint amilyen a filmben Penélope Cruznak. Továbbá betekintést nyerhettünk abba is, hogy egy színész hogyan reprodukálja azt, amikor egy karakter sír.

Amellett, hogy a program nagyon érdekes volt, remek hangulat uralkodott a felvétel alatt, hiszen a filmek világa müfajtól függetlenül mindenkihez közel áll, a szinkronstúdiók müködésének testközelből való megismerése ezért maradandó élményt nyújtott a konferencia vendégeinek számára.

\section{2. nap: Meet the President - AIIC Vega Goes Budapest - Bar Camp}

A konferencia második napja a fenti rejtélyes cím alatt futott, és valójában a Konferenciatolmácsok Nemzetközi Szövetségének (AIIC) fiatal tolmácshallgatók és tolmácsok számára szervezett eseménye volt, melynek vendéglátójául és színhelyéül a szervezet tanszékünket választotta. A szervezet világszerte mintegy 3000, Magyarországon 8 tagot számlál. Választásuk a tanszék számára nagy megtiszteltetés, hiszen a régióban ehhez hasonló eseményre még nem került sor.

A délelőtti program során először a szervezet alelnöke, Paco Garcia Hurtado, majd több tagja tartott előadást arról, hogy mit nyújthat egy tolmácsnak a legnagyobb érdekvédő szervezet a szakmában, és természetesen szórakoztató és elrettentő anekdotákat is hallhattunk a tolmácsok mindennapjaiból. A déle- 
lőtt második részében Tóth Barnabást, a Chuchotage címủ magyar rövidfilm rendezőjét látta vendégül a konferencia. A résztvevő együtt megtekintették a filmet, majd beszélgetés következett a rendezővel a témaválasztásról és a forgatás részleteiről.

Az AIIC délutáni Bar Camp eseménye megfogalmazásuk szerint egy „unconference", ahol ahelyett, hogy a hallgatóság tagjai kényelmesen bóbiskolnának székükön, míg az előadó végtelen monológot mond választott témájáról, a tudásmegosztás interaktívan történik, mindenki részt vesz a beszélgetésben. Az első szabály, hogy legyen egy téma, amiről szívesen beszélsz, és készülj egy 30 perces előadással. A résztvevők témái felkerülnek a sli.do online konferenciaszoftver segítségével egy listára, és szavazással választják ki a listáról, melyik előadást szeretnék hallani. A témák közt szerepelt például a tolmács felkészülése az eseményre, a tolmács szókincsbővítő stratégiái, és az is, hogy mivel ne foglalkozzon a tolmács egy esemény során. Az ötlet érdekes és forradalmi, bár azt hiszem sokakat visszatartott a részvételtől, hogy inkább hallgatni szeretnek, mint előadást tartani.

A délután második része egy brainstorming ülés volt, ahol olyan témákat jelöltek meg a résztvevők, amelyeket szívesen megvitatnának kollégáikkal, majd a sli.do segítségével megszavazták, mely témák kerüljenek terítékre. Az AIIC innovatív, fiatalos lendületű programja egy kötetlen, jókedvü borozással fejeződött be, amely méltó záróakkordja volt a XXI. TransELTE tavaszi konferenciának.

\section{Irodalom}

Balogh, K., Salaets, H. (eds.) 2015. Children and Fustice: Overcoming Language Barriers. Cooperation in interpreter-mediated questioning of minors. Cambridge-Antwerp-Portland: Intersentia. Available at: http://bit.ly/2tphr4w (Letöltve 2019.09.27.) 